\title{
Mythological Criticism Analysis in Novel Ronggeng Dukuh Paruk by Ahmad Tohari
}

\author{
Ratna Sari Dewi ${ }^{1}$ and Masdalifah ${ }^{2}$ \\ ${ }^{1}$ Universitas Negeri Padang, Padang, Indonesia, $ه$ (email), ratnasari@umsu.ac.id
}

\begin{abstract}
This study deals with Mythological Criticism Analysis in Novel Ronggeng Dukuh Paruk by Ahmad Tohari. The objectives of this study are to find out the concept of mythological criticism in Novel Ronggeng Dukuh Paruk, and to find out the dominant concept of mythological criticism in Novel ronggeng Dukuh Paruk. A Library research was conducted to analyze mythological criticism in novel. The data are analyzed by applying descriptive qualitative method. The source of the data is obtained from the novel Ronggeng Dukuh Paruk by Ahmad Tohari. The technique for analyzing the data are used Moleong's theory (2006) . The result found that there were 4 concepts of mythological criticism used in the novel Ronggeng Dukuh Paruk, they are archetype, symbol, character, situation, image. The amount of concepts of mythological criticism in novel Ronggeng Dukuh Paruk by Ahmad Tohari are archetype 37 (21\%), Symbol 32 (18\%), Character 32 (18\%), Situation $41(23 \%)$ and Image 35 (20\%). Situation is the dominant concepts of mythological criticism in novel Ronggeng Dukuh Paruk.
\end{abstract}

Keywords: Mythological Criticism, Archetype, Symbol, Character, Situation, Image

\section{INTRODUCTION}

Novel Ronggeng Dukuh Paruk by Ahmad Tohari describes the social and cultural life of the color of the lower classes. This novel tells the story of where the dancer struggle ronggeng located in remote hamlets in Dukuh Paruk during communist upheaval. Besides Ahmad Tohari pouring religious values in Ronggeng Dukuh Paruk so smooth. Public life found in the novel Ronggeng Dukuh Paruk always obey and uphold the culture of the ancestors.

So the writer is interested to analyze the novel Ronggeng Dukuh Paruk. Henry Van Dyke (2013) Literature consist of those writings which interpret the meaning of nature and life, in words of charm and power, touched with the personality of the author, in artistic forms of permanent interest. This novel becomes a reflection of the life of society, that is used as the literature with the messages in it. The existence of a habit or belief customs and culture were always held in high esteem by the people Dukuh Paruk, who seemed to want to mislead the public Dukuh Paruk. The novel analyzes mythological criticism by finding the myths that has meaning and significance of its own, ethnic and rituals .

The writer wants to explore the power of myth in human lifes, and establishes pattern in the human psyche affects the way of thinking as myths unveil various ideas. There are many more myths that exist in this novel, and it makes people confuse to find the myths and also the concept, therefore the writer wanted to analyze discovering and describing various the concept on the mythological criticism that are archetype, a symbol, character, situation and image. Mythological events occur in the story is mythological character .

\section{METHOD}

This research was conducted by using descriptive qualitative method, because of this study was analyzed mythological critism in novel Ronggeng Dukuh Paruk. The researcher was attented to analyzed mythologycal critism analysis in novel Ronggeng Dukuh Paruk by Ahmad Tohari.The source of data in this research are taken from novel Ronggeng Dukuh Paruk . The researcher uses some dialogues or conversation in this novel as the data. The data was analyzed in Trilogi 1and Trilogi 2.In collecting data, the researcher uses observation nonsystematic, the researcher just read the novel and make a note about sentences and conversation in the novel. According Moleong (2006) to collect the data, the researcher does some steps as follow :

1. Reading the novel of Ronggeng Dukuh Paruk.

2. Identifiying the kinds of mythological critism in the novel.

The data are analyzed by applying the following steps:

1. Identifiying the mythological criticism based on the context was found in Ronggeng Dukuh Paruk.

2. Finding out the dominant context of mythologycal criticism was found in Ronggeng Dukuh Paruk.

The writer uses the following formula, the formula by Moleong (2006: 3) 


$$
\mathrm{X}=\mathrm{F} / \mathrm{N} \times 100 \%
$$

$$
\begin{aligned}
& \mathrm{X}=\text { Average } \\
& \mathrm{F}=\text { Amount of context mythological critism } \\
& \mathrm{N}=\text { Amount of context mythological critism }
\end{aligned}
$$

\section{RESULT AND DISCUSSION}

The data in this research were collected from the 2 trilogi script of Novel Ronggeng Dukuh Paruk. The novel has 4 concept of mythological ; archetype, symbol, character, situation or image. The researcher analyzed the concepts of mythological criticism, which were most dominant of them used in the Novel Ronggeng Dukuh Paruk. In order to find out the dominant types of Mythological Criticism used in, the researcher percentage each concept of Mythological Criticism by using this following of formula :

$$
\mathrm{P}=\mathrm{F} / \mathrm{N} \times 100 \%
$$

The result can be shown on the table below:

\begin{tabular}{ccc}
\hline $\begin{array}{c}\text { Concept of Mythological } \\
\text { Criticism }\end{array}$ & Total & P = F/N X 100\% \\
\hline Archetype & 37 & $21 \%$ \\
\hline Symbol & 32 & $18 \%$ \\
\hline Character & 32 & $18 \%$ \\
\hline Situation & 41 & $23 \%$ \\
\hline An Image & 35 & $20 \%$ \\
\hline Total & 177 & $100 \%$ \\
\hline
\end{tabular}

From the novel that analyzed by the researcher, the writer found that there were 4 concepts of mytholigical criticism, archetype, symbol, character, situation or image.The finding of this study shows that there are 4 concepts of the mythological criticism which consist of archetype, symbol, character, situation, and image. The total of archetype 37, symbol 32, character 32, situation 41 , an image 35 with the percentage $21 \%$ in archetype, $18 \%$ in symbol, $18 \%$ in character, $23 \%$ in situation, and $20 \%$ in an image. The most dominant concepts of this study was situation which contain $23 \%$ in novel Ronggeng Dukuh Paruk by Ahmad Tohari.

\section{CONCLUSION}

Based on the research finding, there are several important things that were taken out as the conclusion of the study, there are:

1.All concepts of Mythological Criticism in Novel Ronggeng Dukuh Paruk. The total concepts of archetype, symbol, character, situation, an image were used in Mythological criticism 37 (21\%), 32 (18\%), 32 (18\%), 41 (23\%), 35 (20\%).

2.Situation 41 (23\%) was the most dominant Mythological Criticim in Novel Ronggeng Dukuh Paruk.

3. The next is archetype $37(21 \%)$, an image (20\%), character $32(18 \%)$, and symbol $(18 \%)$.

\section{REFERENCES}

[1] Annisna. 2013. Archetype Carl Jung. http:www.an nisna.blogspot.co.id/04/archetype/ accessed on September 07, 2017 at $11.45 \mathrm{am}$.

[2] Fard, Farzaneh Saeed. 2016. International Journal Humanities and Culture Studies, A Short Introduction to Literary Criticism. ISSN 23565926.Sarab Iran: Islamic Azad University

[3] Guerin L, Wilfred. etc. 2005. A Handbook of Critical Approaches to Literature, New York: Oxford University Press

[4] Joshua J, Mark. 2009. Definition of Mythology. http://www.ancient.eu/mythology/ accessed on May 02, 2017 at $14.36 \mathrm{pm}$.

[5] Jung, Carl Gustav. 2009. Introduction of Analytical Psychology interpreted by, Agus Cremers, Jakarta: Gramedia

[6] Knawar, Gayatri. 2016. International Journal of E ngineering Technology, Management and Applied Sciences Volume 4, Issue I, The Symbiotic Relation of Mythical Stories in transforming Human Lives. Ijetmas

[7] Kennedy, X. J. and Diana Gioia, 1995. Literature: An Introduction to Fiction, Poetry, and Drama. Sixth Edition. New York: Harper Colllins

[8] Lexy, J, Moleong, 2000.Methodology of Qualitative Research. Bandung: Remaja Rosdakarya

[9] Abrams, M.H. 1993 . “Archetypal Criticism.” A Glossary of Literature Terms. Fort Worth: HBJ

[10] Frye, Northrop. 2001 . "The Archetypes of Literature." The Norton Anthology: Theory and Criticism. Ed. Vincent B. Leitch. New York: Norton.

[11] Knapp, Bettina L. 1984 ."Introduction." A Jungian Approach to Literature. Carbondale and Edwardsville: Southern Illinois University Press, 1984.

[12] Leitch, Vincent B. 2001. "Northrop Frye." The Norton Anthology: Theory and Criticism. Ed. Vincent B. Leitch. New York: Norton.

[13] Segal, Robert A. 1998. "Introduction." Jung on Mythology. Princeton: Princeton University Press

[14] Walker, Steven F. 1995. Jung and the Jungians on Myth. New York: Garland Publishing.

[15] http://www.literarydevices.com/archetype/ accessed on 23 January 2017, $13.21 \mathrm{pm}$.

[16] http://www.soulcraft.co/essays/the 12 common_a rchetypes.html accessed on January 26, 2017 at $18.09 \mathrm{pm}$.

[17] http://profil.merdeka.com/indonesia/a/ahmadtohari/ accessed on January 26, 2017 at $18.09 \mathrm{pm}$.

[18] https://www.hccfl.edu/media/724354/archetypesfo rliteraryanalysis.pdf accessed May 19,2017 at $12.11 \mathrm{pm}$. 